\title{
The Extent of Involvement of Educators in the Formulation of National Education Policies in the Midlands Province of Zimbabwe
}

Willard Nyathi ${ }^{1 *}$, Caxton Shonhiwa ${ }^{2}$

${ }^{1}$ Dean, Faculty of Education, Amadi University

${ }^{2}$ Senior Lecturer, Faculty of Commerce, Zimbabwe Open University

DOI: $10.36347 /$ sjahss.2020.v08i09.010

| Received: 03.09.2020 | Accepted: 11.09.2020 | Published: 25.09.2020

*Corresponding author: Willard Nyathi

\section{Abstract}

The aim of the present study was to establish the role played by educators in the formulation of education policies in the Midlands Province in Zimbabwe. The study employed the quantitative methodology and adopted the descriptive survey design. The population was made up of all the teachers, heads of schools, education inspectors, district education officers as well as teacher union leaders. The Midlands Province has an establishment of plus or minus 18000 educators. The sample consisted of 440 educators made up of 350 classroom practitioners, 68 heads of schools, 3 District Schools Inspectors, 9 Education Inspectors and 10 union leaders selected using stratified random sampling. Data were collected using the questionnaire and interviews. The study revealed that policies are made, revised, implemented and abolished on a continuous basis with little or no input from educators. Policy-makers do not involve educators in the policy-making process because they believe that they do not have the capacity to meaningfully contribute during the policy-formulation process the study recommends that the Ministry of Primary and Secondary Education should consult educators widely on matters concerning policy making if policies are to be implemented without antagonism and resistance.

Keywords: Educators, education policy, involvement, policy formulation, province.

Copyright @ 2020: This is an open-access article distributed under the terms of the Creative Commons Attribution license which permits unrestricted use, distribution, and reproduction in any medium for non-commercial use (NonCommercial, or CC-BY-NC) provided the original author and source are credited.

\section{INTRODUCTION}

In Zimbabwe, like in many countries, various educational policies are formulated to regulate the operations of the education system [1]. Most policies (if not all) that are formulated for the education system should be implemented by educators in their various capacities. As Mlahleki [2] posits, policy implementation is a process of putting policy into action and there must be individuals or groups of people who seek to translate objectives of the policy into action. Implementation of policy implies that the objectives must be achievable or capable of being translated into action [2]. According to Chiwaro and Manzini [3] most education policies in Zimbabwe are not implemented as planned because those who should put them into action either do not understand the intentions of these policies or are uninterested to implement them because they feel they were left out during the formulation of these policies.

As Moyo [4] argues, resistance is inevitable when teachers feel threatened about the policies formulated without their input. The importance therefore of ownership of policies is paramount for successful implementation of policies. It is because of this information that this study sought to evaluate the extent of involvement of educators during the policymaking process in Zimbabwe.

\section{LITERATURE REVIEW}

Generally, policy as seen by Makinde [5] is a purposive course of action taken by those in power in pursuit of certain goals or objectives. A policy should contain its purpose in an ambiguous way and in the case of educational policies; they should be specific on why and how they came to exist [6]. For example, in the case of the policy on education for all in Zimbabwe, it came into existence because there was social demand for education due to colonial imbalances [7]. Hambleton and Dey [8] argue that a policy should also be clear about achieving certain objectives as well as the target group and why the group has been selected or not.

Chiwaro and Manzini [3] define educational policy as a guide about those involved in planning, 
decision making, implementation and other activities in education administration on how theyshould behave., Chisholm et al. [9] state that in Zimbabwe traditionally policy formulation is preceded by appointment of commissions of inquiry into education. There are many commissions that have been appointed to look into the education system in Zimbabwe and the most prominent one was the 1999 Presidential Commission headed by Professor Nziramasanga [25]. This, according to Madziyire [10], then implies that policy formulation in Zimbabwe is consultative and that issues are resolved by consensus. However, inspite of this ideal situation Kumar and Scuder [11] argue that policymaking often is considered a priviledge and is jealously guarded by those in authority.

Makinde [5] posit that in spite of the various channels thought to be available for educators to express their opinions, many teachers view policy decisions as being forced upon them from a hierarchical power structure that enforces policy mandates in a topdown submission. This means that as Deepta [12] posits, the top-down approach is at play whereby the teachers will implement the policies but to a limit that will not upset the status-quo. Zhou and Hardlife [13] note that when prescriptive policies are created without teachers' input a school's ability to meet the needs of students and parents is reduced.

Chisi and Nsingo [9] support the idea of involving teachers when they suggest that in a democratic social order, the citizens, the educational professionals, politicians or economists, all participate in educational policy formulation. Participation in the policy formulation process among teachers who generally feel marginalized from the policy process is crucial [14]. Bartel [15] adds that if the voice of the teacher educators is to be heard teacher inputs must be created in formulating educational policy. When teachers have a say in the formulation of education policies they become empowered [16]. Bernis and Nanus [17] observe that leaders empower others to translate intention into reality and sustain it, which means that empowerment is not power over others but power with others and therefore teachers should be allowed to contribute to their demands, needs and intentions.

Gratch [18] bemoans the power of the state, the silencing and isolation of teachers as negatively impacting progressive change in schools. Teachers were not included in the policy-making process due to the inherent barriers within the larger system [18]. As Zengeya [19] advises, teachers should be provided with opportunities to make decisions and voice their opinions on school policies. Therefore, shared vision in educational policy formulation should accommodate views from all stakeholders including teachers [19]. Wildavsky [20] states that many well-intentioned education programmes and reforms failed to succeed because policy makers did not take into account the centrality of teachers who implement these programmes on the ground. According to Zhou and Hardlife [13], shared vision involved establishing a policy with a sense of purpose and persuasive rationale to ensure that policy is not abandoned.

The issue of communication between policy makers and educators bridges the gaps that result when discourse is not aligned among groups. When policymaking is carried out effectively, such a process can produce general awareness of the problems, neutralize potential opposition and mobilize support for the difficult policy choices [18]. The importance of participation and consultation was stressed by Ham and Hill [8] who postulate that heads and teachers should be involved in the policy formulation process because they are the source as well as the support system for any government policy since teachers have direct experience with children and parents hence their provision of ideas and views should not be ignored.

As Sawyer [21] observes, educators are often the forgotten lot when it comes to policy -making and yet they have critical influence at various stages of the policy marking process. Gratch [18] blames the state when she states that the state has power to silence teachers by isolating them within the hegemonic discourse of schools as a fundamental piece of structural theory and as a result this excessive power can result in cynicism and mistrust by stakeholders. In the end as Gratch [18] postulates, educators accept ownership and responsibility of policies as a gesture of patriotism than professionalism. Zvobgo [22] notes that unprogressive civil servants (educators included) can sabotage the policy-making process as a result of frustration due to a feeling of marginalization. If teachers are not involved in the policy-making process they may remain illiterate and incompetent in matters of formulating policies and this would result in lack of expertise by the educators [18].

\section{Statement of the Problem}

The success and failure of education policies hinges upon the willingness of educators to put policies into genuine action. Teachers and other educators ought to fully understand the intentions of education policies and have a buy-in if ever these policies are to have high chances of success in the schools.

\section{Significance of the study}

The study sought to establish the involvement of educators in the policy making process in order to expose the gaps in the consultation process and come up with strategies to promote the participation of educators in the policy making process.

\section{Research Questions \\ The study addresses the following sub- questions:}


1. Are educators aware of the importance of educational policies?

2. Does the Ministry of Primary and Secondary Education consult educators during the process of policy formulation?

3. Do educators perceive themselves as major stakeholders in the policy-formulation process of educational policies?

4. What are the factors that militate against involvement of educators in formulating educational policies?

5. What are the consequences of neglecting inputs from educators during the policy making process of educational policies?

\section{Delimitations of the study}

The study focused on 350 classroom practitioners, 68 heads of schools, 3 district education officers, 9 education inspectors and 10 union leaders from one of Zimbabwe's ten provinces which is the Midlands Province. Views from the Provincial Education Director, Civil Service Commission Inspectors and legislators were not solicited for.

\section{Limitations of the study}

The study limited itself to the evaluation of the involvement of educators in the policy formulation process of educational policies in Zimbabwe's education system. The descriptive research design that the study employed presents the possibility for error and subjectivity. As Descombe [23] contends, the study may contain errors as the researcher may record what they want to hear and ignore data that does not conform to the research projects' hypothesis. This was mitigated by the use of triangulation within methods.

\section{METHODOLOGY}

The study adopted the quantitative research paradigm and made use of a descriptive survey research design. According to Khan [24] the descriptive survey design looks with intense accuracy at the phenomenon of the moment and then describes precisely what the researcher sees. The questionnaire and the structured interview were used as the instruments for collecting data. The population constituted the entire plus or minus 18000 educators from the Midlands Province. Stratified random sampling was used to arrive at a sample of 350 classroom practitioners, 68 heads of schools, 3 District Education Officers, 9 Education Inspectors and 10 teacher trade union leaders across the Province.

Questionnaires were distributed in the selected schools through the heads of schools and collected by the researcher from the heads after two weeks. Interviews were conducted with district education officers, Education inspectors and teacher trade union leaders in a period spanning over one month due to the wide distances involved travelling across the province. Data from the questionnaire produced descriptive statistics around the variables understudy. These statistics were computed and inferential implications from them derived and recorded. Information from the interviews was recorded and analysed using the Weft QDA software package.

\section{FINDINGS AND DISCUSSION}

The study set out to evaluate the extent of involvement of educators in the formulation of educational policies in Zimbabwe. This section is presented in two parts; namely, presentation of data and discussion thereof.

\section{Presentation of Data}

Table-1: Category of respondents $(\mathrm{N}=440)$

\begin{tabular}{|l|c|c|}
\hline Category & Frequency & Percentage \\
\hline District Education Officers & 3 & 1 \\
Education Inspectors & 9 & 2 \\
Union Leaders & 10 & 2 \\
Heads & 68 & 15 \\
Teachers & 350 & 80 \\
\hline Totals & $\mathbf{1 2 0}$ & $\mathbf{1 0 0}$ \\
\hline
\end{tabular}

The bulk of the respondents (80\%) were teachers which are a true reflection of the composition of educators in the education system and most policies are implemented in the classroom where teachers work.
Other educators were also represented as follows; heads of schools $(15 \%)$ union members $(2 \%)$ education inspectors $(2 \%)$ and district education officers $(1 \%)$ respectively.

Table-2: Distribution of respondents by sex $(\mathrm{N}=440)$

\begin{tabular}{|c|c|c|c|c|c|c|c|c|c|c|c|c|}
\hline Category & \multicolumn{2}{|c|}{$\begin{array}{l}\text { District Education } \\
\text { Officers }\end{array}$} & \multicolumn{2}{|c|}{$\begin{array}{l}\text { Education } \\
\text { Inspectors }\end{array}$} & \multicolumn{2}{|c|}{$\begin{array}{l}\text { Union } \\
\text { Leaders }\end{array}$} & \multicolumn{2}{|c|}{ Heads } & \multicolumn{2}{|c|}{ Teachers } & \multicolumn{2}{|c|}{ Totals } \\
\hline & $\mathbf{F}$ & $\%$ & $\mathbf{F}$ & $\%$ & $\mathbf{F}$ & $\%$ & $\mathbf{F}$ & $\%$ & $\mathbf{F}$ & $\%$ & $\mathbf{F}$ & $\%$ \\
\hline Male & 3 & 100 & 8 & 89 & 10 & 100 & 60 & 88 & 160 & 45 & 241 & 55 \\
\hline Female & 0 & 0 & 1 & 11 & 0 & 0 & 8 & 12 & 190 & 55 & 199 & 45 \\
\hline Totals & 3 & 100 & 9 & 100 & 10 & 100 & 68 & 100 & 350 & 100 & 440 & 100 \\
\hline
\end{tabular}


The information on table 2 above shows that the majority of respondents $(55 \%)$ were male and $45 \%$ were female. The gender variance was pronounced among the district education officers, education inspectors, union leaders as well as heads in favour of males (100\% male: $0 \%$ female; $89 \%$ male: $11 \%$ female; $100 \%$ male: $0 \%$ female and $88 \%$ male: $12 \%$ female respectively). Only amongst the teachers were the females more than the males. (55\% female: $45 \%$ male).

Table-3: Composition of respondents by professional qualifications $(\mathrm{N}=440)$

\begin{tabular}{|l|c|c|}
\hline Professional Qualifications & Frequency & Percentage \\
\hline Certificate in Education & 24 & 6 \\
Diploma in Education & 317 & 72 \\
Bachelor's Degree & 85 & 19 \\
Masters Degree & 8 & 2 \\
Others & 6 & 1 \\
\hline Totals & $\mathbf{4 4 0}$ & $\mathbf{1 0 0}$ \\
\hline
\end{tabular}

Table 3 above shows that $72 \%$ of the respondents were Diploma in Education holders, $19 \%$ had first degrees, $2 \%$ had Masters degrees, $6 \%$ held the
Certificate in Education qualification and $1 \%$ were not classifiable.

Table-4: Responses to the question: "Are you aware of all education policies formulated by the Ministry of Primary and Secondary Education?" (N=418)

\begin{tabular}{|l|c|c|c|c|c|c|}
\hline Responses & \multicolumn{2}{|c|}{ Heads } & \multicolumn{2}{c|}{ Teachers } & \multicolumn{2}{c|}{ Totals } \\
\hline Strongly Agree & 68 & 100 & 240 & 69 & 308 & 74 \\
Agree & 0 & 0 & 90 & 26 & 90 & 21 \\
Disagree & 0 & 0 & 7 & 2 & 7 & 2 \\
Strongly Disagree & 0 & 0 & 8 & 2 & 8 & 2 \\
Not sure & 0 & 0 & 5 & 1 & 5 & 1 \\
\hline Totals & $\mathbf{6 8}$ & $\mathbf{1 0 0}$ & $\mathbf{3 5 0}$ & $\mathbf{1 0 0}$ & $\mathbf{4 1 8}$ & $\mathbf{1 0 0}$ \\
\hline
\end{tabular}

The information on Table 4 above shows that all heads $(100 \%)$ indicated that they were aware of all the education policies formulated by the Ministry, $95 \%$ of the teachers also indicated that they were aware of policies on education. Only a few teachers indicated that they were not aware and unsure $(4 \%$ and $1 \%$ respectively).

Table-5: Responses to the question; “Are you consulted during policy formulation?" (N=418)

\begin{tabular}{|l|c|c|c|c|c|c|}
\hline Responses & \multicolumn{2}{|c|}{ Heads } & \multicolumn{2}{c|}{ Teachers } & \multicolumn{2}{c|}{ Totals } \\
\hline Strongly Agree & 1 & 1 & 0 & 0 & 1 & 0 \\
Agree & 7 & 25 & 5 & 1 & 22 & 5 \\
Disagree & 19 & 28 & 50 & 15 & 69 & 17 \\
Strongly Disagree & 31 & 46 & 290 & 83 & 321 & 77 \\
Not sure & 0 & 0 & 5 & 1 & 5 & 1 \\
\hline Totals & $\mathbf{6 8}$ & $\mathbf{1 0 0}$ & $\mathbf{3 5 0}$ & $\mathbf{1 0 0}$ & $\mathbf{4 1 8}$ & $\mathbf{1 0 0}$ \\
\hline
\end{tabular}

Table 5 above shows that both teachers and heads were in concurrence that they were not consulted during the policy formulation process $(74 \%$ : heads and $98 \%$ : teachers respectively). Only $26 \%$ of the heads stated that they were consulted. Overall, $94 \%$ of the respondents indicated that they were not consulted during the policy making process.

Table-6: Responses to the question: "Who should be the most important stakeholder when formulating educational policies? $(\mathrm{N}=\mathbf{4 1 8})$

\begin{tabular}{|l|c|c|}
\hline Category of responses & Frequency & Percentage \\
\hline The State & 64 & 15 \\
Politicians & 13 & 3 \\
Educators & 326 & 78 \\
Donors & 13 & 3 \\
Not Sure & 4 & 1 \\
\hline Totals & $\mathbf{4 1 8}$ & $\mathbf{1 0 0}$ \\
\hline
\end{tabular}


Table 6 above shows that $78 \%$ of the respondents indicated that educators were the major stakeholders when formulating policies. Those who said it is the state were $15 \%$ of the respondents and $3 \%$ apiece stated that politicians and donors are the most important stakeholders during the policy-making process and only $1 \%$ was not sure about the question.

Table-7: Responses to the question: "What do you consider to be the reasons for lack of involvement by educators in the policy-making process?" $(\mathrm{N}=418)$

\begin{tabular}{|l|c|c|}
\hline Reasons & Frequency & Percentage \\
\hline Educators are seen as craft illiterate & 330 & 79 \\
\hline Educators have little time & 42 & 10 \\
\hline Lack of resources & 46 & 11 \\
\hline Totals & $\mathbf{4 1 8}$ & $\mathbf{1 0 0}$ \\
\hline
\end{tabular}

The information on table 7 above shows that $79 \%$ of the respondents indicated that the reason why educators were left out of the policy-making process was that policy-makers thought they lacked the craft literacy to contribute meaningfully.

The researcher interviewed the district education officers, education inspectors and union leaders on the involvement of educators in the policymaking process. Respondents were asked to explain how educational policies were formulated in Zimbabwe. The majority of the respondents stated that the majority of policies are imposed from above. Where educators are involved it is through mere consultation to explain the new policies to them for implementation. All the three categories of respondents concurred that educators were supposed to be involved throughout the policymaking process rather than at the implementation stage. District education officers and education inspectors blamed teacher unions for their failure to compel the Ministry to involve educators in the policyformulation process. Respondents also stated that most policies in the education sector were not fully implemented due to the marginalization of educators during their formulation.

\section{DISCUSSION}

Results from the study reveal that most educators are in possession of relevant professional qualifications. The implication of this situation is that the educators with relevant qualifications are most likely to contribute meaningfully during the policy making process as the majority of them are aware of the various policies that are promulgated and affect their operations. This is in congruence with the assertion by Mlahleki [2] who posits that policy implementation is a process of putting policy into action and there must be individuals or groups of people who seek to translate objectives of the policy into clear and specific actions.

It is very evident that educators are not involved in the policy-making process and yet they perceive themselves as the most important stakeholder in the education making process. Participation in the policy formulation process among educators who generally feel marginalized from the policy process is very crucial. As Bartel [2] argues, if the voice of the teacher educators is to be heard, teacher inputs must be created in formulating educational policy. And Chiromo [16] adds that when teachers have a say in the formulation of education policies they become empowered and leaders who empower others to translate intention into reality and sustain it means that empowerment is not power over others, but power with others.

Educators believe that the major reason for their lack of involvement is due to the marginalization they experience from policy-makers due to the fact that they are viewed as being unable to contribute meaningfully in the policy-making process. This confirms Sawyer [21]'s observations that educators are often the forgotten lot when it comes to policy-making and yet they have critical influence at various stages of the policy-making process. Gratch [18] puts its even more crudely when he states that the State has power to silence teachers by isolating them within the hegemonic discourse of schools as fundamental piece of structural theory and as a result of this, excessive power can result in cynicism and mistrust by stakeholders.

Results from this study also reveal that most policies in Zimbabwe's education system are imposed form above and educators are required to implement them without question. Surprisingly, even trade unions representing educators play a very marginal role in the policy-making process. This tallies with observations by Makinde [5] who posit that in spite of the various channels thought to be available for teachers to express their opinions, many teachers view policy decisions as being forced upon them from a hierarchical power structure that enforces policy mandates in a top-down submission. Moyo [4] states that resistance is inevitable when teachers feel threatened about the policies formulated without their input. The importance of full ownership of policies by educators is paramount for successful implementation of policies.

\section{CONCLUSIONS}

Given the background of the above findings, the researcher makes the following conclusions:

- Educators are in possession of relevant professional qualifications that would make it 
easy for them to be effectively incorporated in the policy-making process.

- Educators are not involved in the policymaking process and yet they perceive themselves as the most important stakeholder in any educational policy.

- Policy-makers do not involve educators in the policy-making process because they believe that they do not have the capacity to meaningfully contribute during the policyformulation process.

- Most policies in the Zimbabwean education system are imposed from above and educators are required to implement them without question.

- Trade union organisations in the education sector play a very insignificant role in the policy-making process and they are like little puppies that bark at an elephant ravaging on the home stead's field crops as they only protest after unpopular policies have been promulgated.

\section{RECOMMENDATIONS}

In light of the findings of this study, the researcher would like to make some recommendations.

- The Ministry of Primary and Secondary Education should create mechanisms for the involvement of educators in the policy-making process so that educators gain experience and knowledge of formulating policies.

- The top-down model of policy-making should by complemented by more participatory models of policy-making process.

- Education trade unions should increase their involvement in the policy-making so that they are not seen as merely endorsing what the Government has done as this may render their existence irrelevant in the eyes of their membership.

- Educators should be staff developed on the policy-making process so that they understand the intricate aspects of policy-making.

\section{REFERENCES}

1. Kapfunde CL. An analysis of factors that influence the shaping of educational policy in Zimbabwe. Harare: University of Zimbabwe; 1999.
2. Mlahleki M. The post-colonial state and education policy. Harare: Zimbabwe Open University; 1995.

3. Chiwaro SD and Manzini MM. Introduction to policy studies. Harare: University of Zimbabwe; 2015.

4. Moyo JN. The politics of administration: Understanding bureaucracy in Africa. Harare: Sapes Books; 2012.

5. Makinde T. Problems of policy implementation in developing nations: The Nigerian experience. Journal of Social sciences. 2005 Jul 1;11(1):63-9.

6. Sapru K. Public policy formulation, implementation and evaluation. New Delhi: Sterling Publishers. 2014.

7. Mandaza I. The political economy of transition 198041986. Dakar: CODESRIA. 2016.

8. Hambleton R and Dey S. Teacher's voice in educational policy making. London: Routledge. 2008.

9. Chisi R, Nsingo SA. Educational policy-making process. Harare: Zimbabwe Open University. 2004.

10. Madziyire NC. Introduction to the policy-making process. Harare: Zimbabwe Open University. 2010.

11. Kumar B and Scudar T. Teacher voices in educational policy-making. New York: Longman. 2010.

12. Chopra D. Policy making in India: A dynamic process of statecraft. Pacific Affairs. 2011 Mar 1;84(1):89-107.

13. Zhou G and Hardlife Z. Public policy making in Zimbabwe: A three decade perspective. International Journal of Humanities and Social Science. 2012; 2(8)4: $1-11$.

14. Milbrath L. Environmental policy and the involvement of the grassroot stakeholders. A Francisco: African Educational Research Association. 2001.

15. Bartel M. Creativity killers. New York: Longman.2011.

16. Chiromo S. Motivation in the workplace. Harare: Longman. 2010.

17. Bernis W and Nanus B. Leaders: The strategies for taking charge. New York: Harper and Row. 2008.

18. Gratch A. The culture of teaching and beginning teacher development. London: Routledge. 2012.

19. Zengeya B. Policy-making in the education sector. Harare: Zimbabwe Open University. 2010.

20. Wildavsky A. The art and craft of policy analysis. London: MacMillan.2007.

21. Sawyer L. Revamping a teacher evaluation system. Educational Leadership. 2011; 58(5): 44-47.

22. Zvobgo RJ. The state ideology and education. Gweru: Mambo Press.2016.

23. Descombe. The good research guide. Buckingham: Open University Press; 2010.

24. Khan JV. Research in education. Boston: Allyn and Bacon; 2003.

25. Nziramasanga CT. Report on the Presidential Commission of Inquiry into Education. Harare: Government Printers; 1999. 